\title{
ANALYSIS OF COCOA SUPPLY RESPONSE IN INDONESIA
}

\author{
Ghufron Wahyu Priyo Cahyono*, Ratya Anindita, Condro Puspo Nugroho
}

\author{
Agriculture Department, Brawijaya University, Indonesia \\ Corresponding author: ghufron_id@student.ub.ac.id
}

\begin{abstract}
Cocoa is one of the plants used as raw material for making chocolate, where chocolate is currently popular in the world and in Indonesia. This makes cocoa consumption continue to increase. Increased cocoa consumption must be balanced with an increase in cocoa production. However, it turns out that cocoa production in Indonesia in the last five years has decreased, in addition to the condition of cocoa plantations in Indonesia that have the potential to increase. This study aims to analyze the factors that affect the supply of cocoa in Indonesia based on the number of cocoa plants produced, to analyze the factors that affect the supply of cocoa in Indonesia based on the level of cocoa crop productivity, and to estimate the elasticity of cocoa supply in the short term and long term in Indonesia. The method used in this study is co-integration test and Error Correction Model. based on the results of the analysis, it is known that the factors that influence the cocoa supply response based on the number of plants, namely the price of cocoa beans in the previous three years, interest rates in the previous three years, the number of cocoa plants produced in the previous year Influential in positive and CPO prices in three the previous year Influential in negative. Meanwhile, the factors that influence the supply of cocoa based on the level of crop productivity, namely the price of cocoa beans in the current year Influential in positive and the price of urea fertilizer in the current year Influential in negative. The short-term elasticity of cocoa supply is 0.189 and the long run is 0.347 , where both are not elastic. Increased supply response can be done by government intervention to provide input subsidies to farmers and maintain maintenance on plantations so that production is high.
\end{abstract}

Keywords: Supply, Error Correction Model, Elasticity.

http://dx.doi.org/10.21776/ub.agrise.2020.020.1.10

Received 15 May 2019

Accepted 11 September 2019

Available online 31 January 2020

\section{INTRODUCTION}

Cocoa (Theobrema cacao L.) as one of the plantations used for food. Cocoa is used as raw material for making chocolate that is popular in the world and in Indonesia. This is due to the high level of cocoa consumption. According to Direktorat Jenderal Industri Agro (2015), cocoa consumption in Indonesia continued to experience the largest increase in 2013, which amounted to $86.82 \%$ with the amount of consumption in the previous year amounting to 68.61 thousand tons to 128.18 thousand tons. On the other hand, cocoa production in Indonesia has decreased. This condition can provide an opportunity for Indonesia to increase the amount of cocoa production to meet the needs of world cocoa. Besides the potential of cocoa cultivation owned by Indonesia, like one of the

largest cocoa producers in the world, the country with the largest area of cocoa plants produces the world's second largest, and is the world's third largest cocoa exporting country.

The current decline in the amount of cocoa production in Indonesia is thought to be caused by a decrease in the area of cocoa land in Indonesia, one of the reasons for this is the land conversion. The conversion of cocoa land into other commodity crops caused by other commodities is considered more profitable, such as oil Nurmedika, Basir, \& Damayanti, (2015). In addition, it is also thought to be caused by the low productivity of cocoa plants. This is consistent with the opinion of Rubiyo \& Siswanto (2012), that productivity can be influenced by the use of recommended superior cocoa seedlings, old plant age, erratic weather conditions, pest and disease attacks, and lack of care and 
maintenance also cause land conditions poorly maintained and unproductive .

The large demand for cocoa in Indonesia, which is not offset by increased production, has made cocoa prices in Indonesia increase. This is because when consumer demand increases, producers can raise the selling price of the product. The increase in cocoa prices will also have an impact on the supply of cocoa in Indonesia, where when the cocoa price is high, farmers will respond to increase cocoa production (Madura, 2007). According to Pusat Data dan Informasi Pertanian (2017), the increase in cocoa prices in Indonesia occurred from 2007-2016 with the highest price in 2016 which reached Rp. $24,871 / \mathrm{Kg}$ the lowest price in 2005 was Rp. 9,034/ $\mathrm{Kg}$ or with an average growth of $11.12 \%$ per year. Changes in the number of products offered cannot be obtained directly by cocoa farmers because cocoa is an annual plantation commodity that requires a long period of time (lag time) in obtainingproduction from the cultivation process. This condition is in accordance with the statement of Anindita (2008) that agricultural products have a relatively long response to increase production compared to other commodities outside agriculture.

Based on the description of the condition of cocoa in Indonesia and its potential, the increase in production is needed so that research needs to be made on the factors that influence the supply of cocoa in Indonesia. This study aims to analyze the factors that influence the number of cocoa crops produced and the level of crop productivity determined by the response of farmers to increasing prices and other factors that influence it and to determine the level of elasticity of the cocoa supply in response in Indonesia.

\section{RESEARCH METHODS}

Research on the cocoa supply response in Indonesia uses a quantitative descriptive approach. Location determination in this study used purposive methods. This study uses secondary data from 1986-2016 obtained from relevant agencies such as Badan Pusat Statistik, Ministry of Agriculture, Director General of Plantation, Bank Indonesia, International Cocoa Organization (ICCO), and other supporting institutions.

The model used in this study were adopted from research Dellal \& Koç (2003), regarding the apricots supply response in Turkey which is a development of the model of French \& Matthews (1971), regarding the annual crops supply response, where the use of this model has been adapted to the condition of the research location and the data that the researchers have. The following models are used in this study:

1. Number of cacao producing plants (TM)

$\operatorname{lnJTM}_{\mathrm{t}}=\mathrm{f}\left(\operatorname{lnPkP}_{\mathrm{t}-3}, \operatorname{lnPCPO} \mathrm{t}_{\mathrm{t}-3}, \operatorname{lnSBI} \mathrm{S}_{\mathrm{t}-3}\right.$,

$\ln J \mathrm{TM}_{\mathrm{t}-1}$ )

2. The level of productivity of cocoa plants

$$
\ln \mathrm{Y}_{\mathrm{t}}=\mathrm{f}\left(\ln \mathrm{PkP}_{\mathrm{t}}, \ln \mathrm{PPU}_{\mathrm{t}}, \ln \mathrm{Y}_{\mathrm{t}-1}\right)
$$

Notes:

$\ln \mathrm{JTM}_{\mathrm{t}}=$ The number of cocoa plants producing in year t TM (Tree)

$\operatorname{lnPkPt}-3=$ Cocoa prices at producer level in yera $\mathrm{t}-3$ (IDR / Kg)

lnPCPOt-3= Price of domestic CPO in year t-3 (IDR $/ \mathrm{Kg}$ )

$\operatorname{lnSBIt}-3=$ Interest rate in year t-3 $(\%)$

lnJTMt-1 = Number of cocoa plants produced (TM) in year t-1 (Tree)

$\ln \mathrm{Yt}=$ The level of productivity of cocoa plants in year $\mathrm{t}(\mathrm{Kg} / \mathrm{Tree})$

$\operatorname{lnPkPt}=$ Cocoa prices at producer level in year $\mathrm{t}$ (IDR / Kg)

lnPPUt $=$ Price of urea fertilizer in year $\mathrm{t}-1$ (IDR / $\mathrm{Kg})$

$\operatorname{lnYt}-1=$ The level of productivity of the previous year's cocoa plant (Kg / Tree)

Furthermore, to find out the long and short term elasticities according to Gujarati (2010), the following equations can be used:

$$
\begin{aligned}
& \mathrm{E}_{(\mathrm{sr})}=\frac{\mathrm{dX}}{\mathrm{dK}} \times \frac{\mathrm{K}}{\mathrm{X}} \\
& \mathrm{E}_{(\mathrm{lr})}=\frac{\mathrm{E}(\mathrm{sr})}{\delta} \\
& \text { Where: }
\end{aligned}
$$

$\mathrm{E}(\mathrm{sr})=$ Supply elasticity in the short term

$\mathrm{E}(\mathrm{lr})=$ Supply elasticity in the long term

$\mathrm{dX} / \mathrm{dK}=$ Value of changes in goods offered to cocoa prices

$\mathrm{X}=$ Average dependent variables (average number of cocoa plants produced and the level of crop productivity)

$\mathrm{K}=$ Average independent variable (cocoa price)

\section{RESULTS AND DISCUSSION}

\section{Stationarity Test}

Testing in this study begins with testing data stationarity on each variable used. This is done to determine the stationary level of data in time series data. The following are the results of stationarity tests on each variable used in this study: 
Table 1. Stationary Test Results

\begin{tabular}{|c|c|c|c|c|c|c|}
\hline \multirow[b]{2}{*}{ Variable } & \multicolumn{2}{|c|}{ Level Stage } & \multicolumn{2}{|c|}{ 1st Difference Stage } & \multicolumn{2}{|c|}{ 2nd Difference Stage } \\
\hline & $\begin{array}{l}\text { Dickey-Fuller } \\
\text { Test Statistic }\end{array}$ & Information & $\begin{array}{l}\text { Dickey-Fuller } \\
\text { Test Statistic }\end{array}$ & Information & $\begin{array}{l}\text { Dickey-Fuller } \\
\text { Test Statistic }\end{array}$ & Information \\
\hline $\operatorname{lnJTMt}$ & $-5,359 *$ & $\mathrm{~S}$ & $-3,769 *$ & $\mathrm{~S}$ & $-7,483 *$ & $\mathrm{~S}$ \\
\hline $\operatorname{lnPkPt}-3$ & $-1,299$ & TS & $-2,344$ & TS & $-3,105^{*}$ & $\mathrm{~S}$ \\
\hline $\operatorname{lnPCPOt}-3$ & $-0,216$ & $\mathrm{TS}$ & $-3,339 *$ & $\mathrm{~S}$ & $-3,646^{*}$ & $\mathrm{~S}$ \\
\hline $\operatorname{lnSBIt}-3$ & $-1,122$ & $\mathrm{TS}$ & $-3,101 *$ & S & $-3,984 *$ & S \\
\hline $\operatorname{lnJTMt}-1$ & $-3,160 *$ & $\mathrm{~S}$ & $-2,975 * *$ & $\mathrm{~S}$ & $-6,429 *$ & S \\
\hline $\ln Y t$ & $-3,637 *$ & S & $-8,422 *$ & $\mathrm{~S}$ & $-11,38 *$ & S \\
\hline $\operatorname{lnPkPt}$ & $-0,054$ & TS & $-3,678 *$ & $\mathrm{~S}$ & $-5,542 *$ & $\mathrm{~S}$ \\
\hline $\operatorname{lnPPUt}$ & $-1,584$ & $\mathrm{TS}$ & $-3,083^{*}$ & $\mathrm{~S}$ & $-5,888^{*}$ & $\mathrm{~S}$ \\
\hline $\operatorname{lnYt}-1$ & $-2,359$ & $\mathrm{TS}$ & $-5,247 *$ & $\mathrm{~S}$ & $-8,048^{*}$ & $\mathrm{~S}$ \\
\hline
\end{tabular}

Source: Secondary data processed, 2019

Notes:

S: Stationary TS: Not Stationary

* 5\% significance level

** $10 \%$ significance level

Based on the results of the stationarity test it is known that at the level and intercept level of the data used there are several variables that are stationary at $5 \%$ significance. This can be seen from the absolute value of $\mathrm{ADF}$ statistics smaller than the critical $\mathrm{ADF}$ value on all variables with a significance level of $5 \%$. Besides the level of stationary data can be known from the probability value on each variable greater than 0.05 which means that the data is not stationary or contains unit root at a significance level of $5 \%$. If there are variables that are not stationary, the variables used must be cointegration tests to determine the long-term relationship. Whereas for the Error Correction Model (ECM) test it needs to be transformed again until the variable is stationary at the same level to avoid spurious regression, so that from the stationary test results at the level and intercept level it needs to be transformed so that all data can be stationary at 1 st Difference level and intercept or at the 2nd Difference level and intercept.

2. Estimation Results and Factors Affecting the Response of the Number of Plants Producing Cocoa in Indonesia

Cointegration testing in the study used the EngleGranger method. Data cointegration criteria can be achieved if the statistical DF value is greater than the critical test value at the level with a predetermined significant level. The residual results from the regression test variables used in this study will then be stationary testing to determine the cointegration level of the variables used, following the results of the residual stationarity test from the equation of the number of plants produced.

Table 2. Cointegration Test Results Number of Plants Produce

\begin{tabular}{|c|c|c|c|c|}
\hline \multirow{2}{*}{ Cointegration Test } & \multicolumn{3}{|c|}{ Level stage } & \multirow{2}{*}{ Information } \\
\hline & Test Critical Value* & Dickey-Fuller Test Statistic & Prob. & \\
\hline ECT JTM & $-2,986$ & $-5,684$ & 0,0001 & $\mathrm{~S}$ \\
\hline
\end{tabular}

Based on the table above it can be seen that in the equation the number of cocoa crops produced has a long-term or cointegrated relationship. This is because in the test results the statistical value of DF is greater than the critical statistical value at the level of 5,684 > 2,986. In addition, from the results of the test also obtained a probability value of 0,0001 which means it is smaller than the significance level of 0.05 or 5 percent so that the Augmented Dickey
Fuller (ADF) test results on the residual have been significant and have no unit root. Error Correction Model (ECM) testing can be done if the variables used have long or cointegrated relationships. In the equation of the number of plants produce the variables used have long-term or cointegrated relationships so that Error Correction Model (ECM) can be done. In testing the Error Correction Model (ECM) the variables used must also have stationary 
levels at the same level, namely in this equation at the 2nd Difference level. The following are the estimation results of the Error Correction Model
(ECM) equation for the number of plants producing cocoa.

Table 3. Estimated Estimation of the Response of Cacao Offer Based on the Number of Plants Producing

\begin{tabular}{ccccc}
\hline \multicolumn{5}{c}{ Dependent Variable: $\mathrm{DD}\left(\operatorname{lnJTM}_{\mathrm{t}}\right)$} \\
\hline Variable & Cooefisien & Std. Error & Statistic Test & Prob. \\
\hline $\mathrm{C}$ & $-0,004$ & 0,014 & $-0,290$ & 0,7742 \\
$\mathrm{DD}\left(\operatorname{lnPkP}_{\mathrm{t}-3}\right)$ & 0,188 & 0,077 & 2,437 & $0,0248^{* *}$ \\
$\mathrm{DD}\left(\ln _{\mathrm{nPPO}} \mathrm{t}_{\mathrm{t}-3}\right)$ & $-0,083$ & 0,033 & $-2,472$ & $0,0230^{* *}$ \\
$\mathrm{DD}\left(\operatorname{lnSBI}_{\mathrm{t}-3}\right)$ & 0,106 & 0,078 & 1,347 & $0,1936^{* * *}$ \\
$\mathrm{DD}\left(\operatorname{lnJTM}_{\mathrm{t}-1}\right)$ & 0,456 & 0,188 & 2,420 & $0,0257^{* *}$ \\
ECT $_{\mathrm{t}}$ & $-1,916$ & 0,315 & $-6,066$ & $0,0000^{*}$ \\
\hline R-squared & 0,764256 & & F-Statistic & 12,31921 \\
Durbin-Watson & 2,285615 & Prob(F-statistic $)$ & 0,000020 \\
\hline
\end{tabular}

Source: Processed secondary data, 2019

Notes:

* Significance at a confidence level of $99 \%(\alpha=1 \%)$

** Significance at 95\% confidence level $(\alpha=5 \%)$

*** Significance at $80 \%$ confidence level $(\alpha=20 \%)$

The Error Correction Model (ECM) regression results above are used to determine the relationship of variables in the short term from the cocoa supply response in Indonesia. Based on the results presented in the table above, it can be seen the Error Correction Model (ECM) from the regression results above as follows:

$\operatorname{lnJTMt}=-0.004+0.188 \operatorname{lnPkPt}-3-0.083 \operatorname{lnPCPOt}-$ $3+0.106 \operatorname{lnSBI} \mathrm{t}-3+0.456 \operatorname{lnJTM} \mathrm{t}-1-1,916 \mathrm{ECTt}$

Based on the Error Correction Model (ECM) regression above, it can be seen that the $F$ value of the statistic is 12.31921 with a probability of 0.000020 , and the $\mathrm{F}$ value of the table is 2.09 . This shows that F statistics (12.31921)> F table (2.09) and the probability value is smaller than the specified significance level, 0.1 , so it can be concluded that the independent variables are used together or simultaneously significant effect on the number of cocoa plants produced in the short term and the equations used can be accepted as good estimators.

The results of the analysis above also show the R- squared value of 0.764256 which means that the independent variable used in this equation is able to explain the variation in the dependent variable by $76.42 \%$ while the remaining $23.58 \%$ is explained in other variables outside the variables used. In the regression results also obtained the value of $\mathrm{R}$ squared which has a value of 0.764256 and and the Durbin-Watson value of 2.285615. The value of Durbin-Watson which is greater than the R-squared shows that the regression results that have been done do not occur spurious regression. Based on the results of testing the Error Correction Model (ECM) regression above, it can be seen the probability value. Based on the results of the analysis, the $\mathrm{T}$ test results for each variable are as follows:

a. Cocoa Prices in The Three Years Ago (lnPkPt-3)

The effect of the variable price of cocoa in the three years ago is indicated by the probability value of 0.0248 at the 0.05 significance level. This means that the probability value $(0.0248)<$ significance level (0.05), which means the variable price of cocoa in the previous year significantly affected the confidence level of $95 \%$. The value of the regression coefficient is 0.188 significant regression has a positive influence and every increase in the price of cocoa in the three years ago by $1 \%$, then the number of crops will increase by 0.188 percent. This condition can be related to the law of supply of an item, if the commodity price gets higher, the more the number of commodities will be offered because it will increase the profits obtained (Sugiarto, Herlambang, Brastoro, Sudjana, \& Kelana, 2002). In addition, the price of cocoa beans in the previous three years affected farmers decisions to increase the number of cocoa crops produced due to farmers expectations of the benefits that farmers will get in the long term. This statement is in accordance with the opinion of Aisyah \& Hiola (2017), that the expectations of producers have an influence on supply because if the producer predicts the possibility of increasing prices of goods or services, decreases the prices of production sources, and 
increases consumer income, the producer estimates will increase the size of the supply to consumers.

\section{b. CPO Prices in The Three Years Ago (lnPCPOt-3)}

The CPO price variable in the three years ago has a probability value of 0.0230 at the 0.05 significance level. This means the probability $(0.0230)<$ significance level (0.05), which means that the variable CPO price in the three years ago has a significant effect on the confidence level of $95 \%$. The value of the regression coefficient is -0.083 which means it has a negative influence and every increase in CPO prices in the three years ago is $1 \%$, then the number of crops will be less than 0.083 percent. This is in accordance with the opinion of Anindita \& Baladina (2017), that if the price of one commodity from several commodity-related outputs of the main commodity changes, the other production output will also change. The decline in the number of cocoa plants that produced a decline has occurred due to the conversion of cocoa plantations to oil palm plantations because they are considered more profitable. This is in accordance with the results of the Nurmedika et al., (2015), that the conversion of cocoa land into other commodity crops caused by other commodities is considered more profitable, such as oil palm. The decrease in the number of cocoa produced will have an effect on the production of cocoa produced so that it also has an impact on the decline in cocoa supply in the market.

c. Interest Rate in The Three Years Ago (lnSBIt-3) The variable interest rates in the three years ago have a probability value of 0.1936 at a significance level of 0.2 . This means that the probability value $(0.1936$ ) < significance level (0.2), which means that the variable interest rates in the three years have a significant effect on the $80 \%$ confidence level. The value of the regression coefficient is 0.106 . This means that bank lending rates in the previous three years have a positive influence and each increase in bank lending rates in the three years ago is $1 \%$, then the number of producing plants will increase by 0.106 percent. This is not in accordance with the research of Rizkin \& Rizki (2017), that a decrease in the Bi Rate interest rate will reduce loan interest rates, which will cause demand for credit from companies and households to increase. In addition, a reduction in loan interest rates will also reduce the company's capital costs to invest. This condition is assumed that cocoa farmers individually or in groups are still difficult to access existing capital institutions, so farmers are suspected of preferring to borrow capital from traders. This is in accordance with the results of the study Iqbal \& Dalimi (2006), that the lack of information and knowledge of the farmers and the difficulty of fulfilling the requirements for capital loans from capital institutions such as banks, causes limited access of farmers to existing capital institutions.

\section{d. Number of Plants Produced in Previous Year (lnJTMt-1)}

The variable number of yielding plants in the previous year has a probability value of 0.0257 with a significance level of 0.05 . This means the probability value $(0.0257)>$ significance level (0.05), which means that the variable number of cacao-producing plants in the previous year had a significant effect on the $95 \%$ confidence level. The value of the regression coefficient is 0.456 which means it has a positive influence on the amount of cocoa plants generate in year $t$, where any increase in the number of plants produce cocoa in the previous year by $1 \%$, then the amount of crop yield will increase by 0,456 percent. This is related to the condition of cocoa plants which are annual crops that can be harvested every year, so the number of cocoa plants produced in the previous year will also affect the number of cocoa plants produced in the current year. According to the results of a study by Dellal \& Koç (2003), the number of plants produced in the following period was influenced by the number of plants in the previous year, besides the number of plants in the current year was also influenced by the number of damaged plants in the previous year and the number of new plants in the previous year.

3. Estimation Results and Factors Affecting the Response of Cocoa Productivity Levels in Indonesia

Cointegration testing in the study used the EngleGranger method. Data cointegration criteria can be achieved if the statistical DF value is greater than the critical test value at the level with a predetermined significant level. The residual results from the regression test variables used in this study will then be stationary testing to determine the cointegration level of the variables used, following the results of the residual stationarity test of the plant productivity level equation: 
Tabel 4. Cointegration Test Results of Crop Productivity Levels

\begin{tabular}{ccccc}
\hline \multirow{2}{*}{ Cointegration Test } & \multicolumn{3}{c}{ Level stage } & \multirow{2}{*}{ Information } \\
\cline { 2 - 4 } & Test Critical Value* & Dickey-Fuller Test Statistic & Prob. & \\
\hline ECTY & $-2,971$ & $-6,176$ & 0,0000 & $\mathrm{~S}$ \\
\hline
\end{tabular}

Source: Processed secondary data, 2019

Based on the results of the cointegration test on the productivity level equation of the cocoa plant it can be seen that the residuals have a statistical DF value greater than the critical statistical value at the level of 6,176>2,971. In addition, from the results of the test also obtained a probability value of 0.0000 which means it is smaller than the significant level of 0.5 or 5 percent so it can be concluded that the equation of the level of productivity as a cointegrated cocoa plant. In terms of estimation of crop productivity levels, Error Correction Model (ECM) test the variable used must have the same level of stationarity, in the cocoa plant productivity level equation the vari a bell used is stationary at the level 1st Difference. The following is a table of estimation results of the Error Correction Model (ECM) of the level of productivity of cocoa plants in Indonesia.

Tabel 5. Estimation Results Estimated Bid Response Based on Crop Productivity Levels

\begin{tabular}{ccccc}
\hline \multicolumn{5}{c}{ Dependent Variable: $\mathrm{D}\left(\ln \mathrm{Y}_{\mathrm{t}}\right)$} \\
\hline Variable & Cooefisien & Std. Error & Statistic Test & Prob. \\
\hline $\mathrm{C}$ & $-0,0003$ & 0,021 & $-0,016$ & 0,9868 \\
$\mathrm{D}\left(\operatorname{lnPkP}_{\mathrm{t}}\right)$ & 0,349 & 0,082 & 4,244 & $0,0003^{*}$ \\
$\mathrm{D}\left(\operatorname{lnPPU}_{\mathrm{t}}\right)$ & $-0,286$ & 0,147 & $-1,941$ & $0,0646^{* *}$ \\
$\mathrm{D}\left(\operatorname{lnY}_{\mathrm{t}-1}\right)$ & 0,191 & 0,209 & 0,912 & 0,3710 \\
ECT $_{\mathrm{t}}$ & $-0,988$ & 0,272 & $-3 ., 224$ & $0,0014^{*}$ \\
\hline R-squared & 0,632513 & & F-Statistik & 9.896800 \\
Durbin-Watson & 1,726222 & & Prob(F-statistik $)$ & 0.000083 \\
\hline
\end{tabular}

Source: Processed secondary data, 2019

Notes:

* Significance at a confidence level of $99 \%(\alpha=1 \%)$

** Significance at the trust level of $90 \%(\alpha=10 \%)$

The Error Correction Model (ECM) regression results above are used to determine the relationship of variables in the short term from the cocoa supply response in Indonesia. Based on the results presented in the table above, it can be seen the Error Correction Model (ECM) from the regression results above as follows:

$\operatorname{lnYt}=-0,0003+0.349 \operatorname{lnPkPt}-0.286 \operatorname{lnPPUt}+$ $0.191 \operatorname{lnYt}-1-0.988 \mathrm{ECTt}$

Based on the regression correction error model (ECM) above, we can find the F value of statistics is 9.886800 with a probability of 0.000083 , and a table $\mathrm{F}$ value of 2.31 . This shows that the $\mathrm{F}$ statistic (9.886800) > F table (2.31) and the probability value is smaller than the significant level specified is 0.1 , so it can be concluded that the independent variables used together have a significant effect to the level of productivity of cocoa plants in the short term and the equation used can be accepted as a fairly good estimator.
In the results of the analysis above, it is also known that the R- squared value is 0.632513 which means that the independent variable used in this equation is able to explain the variation in the dependent variable by $63.25 \%$ while the remaining $36.75 \%$ is explained in other variables outside the variables used. In the regression results also obtained the value of R-squared which has a value of 0.632513 and the value of Durbin-Watson is 2.173760. The value of Durbin-Watson which is greater than the R- squared shows that the regression results that have been done do not occur spurious regression. Based on the results of the analysis, the $\mathrm{T}$ test results for each variable are as follows:

a. Price of Cocoa Beans at Year $t(\operatorname{lnPkPt})$

The variable price of cocoa beans in year $t$ has a probability value of 0,0003 at the significance level of 0.01 . This means the probability value $(0,0003)<$ significance level (0.01), which means the variable price of cocoa beans in year $t$ has a significant effect on the level of trustworthiness of $99 \%$. The value of 
the regression coefficient is 0,349 , which means having a positive effect and any increase in the price of cocoa beans in year $\mathrm{t}$ by $1 \%$, than the price of cocoa beans in year $t$ will increase by 0,349 percent. This condition is in accordance with the results of Kindangen, Hartoyo, \& Baga (2017), which states that domestic cocoa prices will positively affect changes in cocoa crop productivity. This is allegedly because the increase in productivity will increase the number of products produced so that it can increase the profits that will be obtained by farmers.

b. Price of Urea Fertilizer in Year $t$ (lnPPUt)

The variable price of urea fertilizer in year $t$ has a probability value of 0.0646 with a significance level of 0.10 . This means that the probability value $(0.0646)<$ significance level $(0.10)$, which means the variable price of urea fertilizer in year $t$ significantly influence the level of trust of $90 \%$. The value of the regression coefficient is -0.286 , which means it has a negative influence and every increase in the price of urea fertilizer in year $t$ is $1 \%$, than theprice of urea fertilizer in year $t$ will decrease by 0.286 percent. The importance of urea fertilizer as an input in cocoa cultivation makes reducing quantity will affect the decline in cocoa productivity. This is because with the increase in the price of urea fertilizer as input cocoa cultivation, farmers will tend to reduce the use of these inputs to reduce production costs so as to decrease the inputs used will also reduce the level of productivity which result in a decrease in cocoa production were obtained. This is in accordance with the opinion of Sardjono (2017), that the price of variable input is one of the factors that influence the amount of production costs incurred by producers. If the production costs incurred are greater then the amount of goods offered will decrease or decrease, on the contrary if the price of production costs drops then the goods offered increase at each price.

c. Level of Productivity of Cocoa Plants in the Previous Year $(\ln Y \mathrm{t}-1)$

The variable level of productivity of cocoa plants in the previous year has a probability value of 0.3710 at the significance level of 0.20 . This means the probability value $(0.3710)>$ significance level (0.20), which means that the variable level of productivity of the cocoa plant in the previous year did not significantly influence the level of confidence of $80 \%$. This is presumably because the productivity of cocoa plants is not only affected by the productivity of the previous cocoa plants, but also influenced by many other input factors. This is consistent with the opinion of Rubiyo \& Siswanto (2012), that productivity can be influenced by the use of recommended superior cocoa seedlings, old plant age, erratic weather conditions, pest and disease attacks, and lack of care and maintenance also cause land conditions kur ang maintained and unproductive.

4. Cocoa Supply Response for Changes in Cocoa Prices in Indonesia

The price supply elasticity is a coefficient that shows the magnitude of the change in the amount of goods offered due to price changes or what can be called the ratio between the percentage change in the number of goods offered to the percentage change in prices (Gilarso, 2003). The value of cocoa supply elasticity in Indonesia can be reflected in the sum of the elasticity of the number of plants produced and the elasticity of the level of crop productivity. The following are the results of estimating the elasticity of cacao offerings in Indonesia

Tabel 6. Results of Estimating Cocoa Offer Elasticity

\begin{tabular}{lcc}
\hline \multicolumn{1}{c}{ Information } & $\mathrm{E}_{(\mathrm{sr})}$ & $\mathrm{E}_{(\mathrm{lr})}$ \\
\hline Cocoa Supply Response & 0,189 & 0,347 \\
\hline Source: Processed secondary data, 2019 & & \\
Information: & & \\
$\mathrm{E}(\mathrm{sr})=$ Short-term elasticity & & \\
$\mathrm{E}(\mathrm{lr})=$ Long-term elasticity &
\end{tabular}

Based on the results of calculations above the elasticity of crop productivity levels, the estimators did not count, because the variable factor of adjustment, namely the number of productivity levels of cocoa plants in the previous year did not significantly influence the level of productivity of cocoa plants in the current year. Based on the above results it can be seen that the value of the cocoa supply elasticity is inelastic in the short term because of the value of elasticity is less than $1(\mathrm{EY}(\mathrm{sr})<1)$. This means that the number of cocoa plants produced in the short term is less responsive to 
changes in cocoa prices in the previous period. In the long term, the elasticity value is 0.347 or inelastic, which means that the number of cocoa plants produced in the long term is less responsive to changes in cocoa prices in the previous period. In the opinion of Anindita \& Baladina (2017), supply elasticity in agricultural commodities will be more elastic over a long period of time, if high price adjustments occur in the short term. Conversely, the shorter the time involved in calculating supply elasticity, the more inelastic supply of a product. But based on the results of the analysis above, the value of elasticity of cocoa supply both in the short and long term is inelastic even though the value of longterm elasticity is more approaching value 1 , so it can be concluded that in the short and long term the cocoa supply response is less responsive to the changes in cocoa prices that occur. This elasticity also influences the substitution of more profitable cocoa commodities because farmers want to get the maximum profit so that changes in the crop will affect production and result in changes in production that are not proportional to price changes.. This is consistent with the opinion of Tothmihaly (2017), that the elasticity of cocoa plants in the short and long term because farmers prefer to choose their crops to other more profitable agriculture such as coffee, CPO, and other.

\section{CONCLUSION}

Based on the results of the analysis above, it can be concluded that:

1.The cocoa supply response in Indonesia based on the number of crops was influenced by the price of cocoa in the previous three years, credit interest rates in the previous three years, and the number of plants in the previous year had a positive effect, while CPO prices in the previous three years had a negative effect.

2.The cocoa supply response in Indonesia based on the level of productivity of cocoa plants is influenced by the price of cocoa beans in the current year and the variable price of urea fertilizer in the current year has a negative effect. Meanwhile, the level of productivity in the previous year did not significantly influence.

3. The response elasticity of the supply of cocoa in the short and long term is inelastic or the value of elasticity is less than one $(E<1)$ which means that in the short and long-term response the offer of cocoa is less responsive to changes in cocoa prices that occur.
Based on the results of previous studies, the authors can provide recommendations namely increasing care by peasants to increase cocoa productivity because to increase the number of cocoa plants farmers are less responsive to price changes. In addition, the author recommends standardization of cocoa yields so as to increase cocoa selling prices

\section{REFERENCES}

Aisyah, \& Hiola, S. K. Y. (2017). Ekonomi Mikro: Aplikasi dalam Bidang Agribisnis. (Rusdiandi Rustan, Ed.). Makassar: CV. Inti Meditama.

Anindita, R. (2008). Pendekatan Ekonomi untuk Analisis Harga. Yogyakarta: Andi Offset.

Anindita, R., \& Baladina, N. (2017). Pemasaran Produk Pertanian. Yogyakarta: Andi Offset.

Dellal, I., \& Koç, A. A. (2003). An Econometric Analysis of Apricot Supply and Export Demand in Turkey. Turkish Journal of Agriculture and Forestry, 27(5), 313-321.

Direktorat Jenderal Industri Agro. (2015). Pengembangan Industri Prioritas Agro. Kementrian Perindustrian.

French, B. C., \& Matthews, J. L. (1971). A Supply Response Model for Perennial Crops. American Journal of Agricultural Economics, 53(3), 478.

Gilarso, T. (2003). Pengantar Ilmu Ekonomi Mikro (2nd ed.). Yogyakarta: Kanisius.

Iqbal, M., \& Dalimi, A. (2006). Kebijakan Pengembangan Agribisnis Kakao Melalui Primatani: Kasus Kabupaten Luwu, Provinsi Sulawesi Selatan. Analisis Kebijakan Pertanian, 4(1), 39-53.

Kindangen, H., Hartoyo, S., \& Baga, L. M. (2017). Perkembangan Produktivitas, Luas Lahan, Harga Domestik, Permintaan dan Ekspor Biji Kakao Indonesia Periode 1990-2013. Jurnal Manajemen \& Agribisnis, 14(2), 118.

Madura, J. (2007). Introduction to Business (4th ed.). Thomson-South-Western.

Nurmedika, Basir, M., \& Damayanti, L. (2015). Analisis Faktor-faktor yang Memengaruhi Pilihan Petani Melakukan Alih Usahatani di Kecamatan Rio Pakava Kabupaten Donggala, 22, 9-20. 
Pusat Data dan Informasi Pertanian. (2017). Outlook Kakao. Sekertariat Jendral Kementrian Pertanian.

Rizkin, A., \& Rizki, C. Z. (2017). Hubungan Kredit Konsumsi, Kredit Investasi dan Suku Bunga dengan Inflasi di Indonesia, 4.

Rubiyo, \& Siswanto. (2012). Peningkatan Produksi dan Pengembangan Kakao (Theobroma cacao L.) di Indonesia. Jurnal Tanaman Industri Dan Penyegar, 3(1), 33-48.
Sardjono, S. (2017). Ekonomi Mikro - Teori dan Aplikasi. Yogyakarta: ANDI.

Sugiarto, Herlambang, T., Brastoro, Sudjana, R., \& Kelana, S. (2002). Ekonomi Mikro - Sebuah Kajian Komprehensif. Jakarta: PT. Gramedia Pustaka Utama.

Tothmihaly, A. (2017). How Low is The Price Elasticity in The Global Cocoa Market? African Journal of Agricultural and Resource Economic, 13(3), 209-223. 
This page is intentionally left blank 